\title{
MAJSTER Z OKOLIČNÉHO A GOTICKÉ UMENIE SPIŠA OKOLO ROKU 1500. DUŠAN BURAN (ED.) SLOVENSKÁ NÁRODNÁ GALÉRIA, BRATISLAVA 2017. 175 OLDAL
}

A Szlovák Nemzeti Galéria nemrég nagyon jelentős kiállítást rendezett az Okolicsnói Mester müveiből. Együtt láthattuk a szlovák múzeumokban őrzött táblákon kívül a majdnem két méter magas szmrecsányi szárnyasoltárokat (!), egy táblát a kassai dómból, néhány okolicsnói és egy késmárki szobrot, de kölcsönöztek táblaképet még Budapestről és Ljubljanából is.

Az Okolicsnói Mester egyike azoknak a régi magyar festőknek, akik viszonylag korán, már 1936-ban szükségnevet kaptak. Müveit, főként a Szépmúvészeti Múzeumban őrzötteket már előbb is minőségüknek megfelelően méltatták, de sokáig nem merült fel, hogy ezek a táblák egyetlen mesterhez kapcsolódnának. Elsőnek Vladimír Wagner pozsonyi professzor ismerte fel, hogy azonos kéz munkái. Ô volt az, aki nevet adott a mesternek, és egyszersmind néhány oltár idesorolásával jelentősen bővítette, sőt stílusának jegyeit gondosan tanulmányozva alapvetően meghatározta oeuvre-jét. ${ }^{1}$

A kiállítás érzékeltetni akarta az Okolicsnói Mester közvetlen környezetét is. Ilyen módon a vállalkozás a festészettörténet és az építészettörténet szempontjából egyaránt fontos eseménnyé vált. Az okolicsnói templom hevesen vitatott alapításának körültekintő bemutatása és az épület hasonlóan részletes (fóként az alapítás kérdéseivel foglalkozó) vizsgálata tölti ki a katalógus húsz teljes lapját. Címének megfelelően a pozsonyi tárlat egy festő és közvetlen környezete bemutatását célozta, így az épület önálló katalógustételt nem kapott, de az egyik teremben számos fénykép, alaprajz, a konstrukciót szemléltető vázlat és néhány rövid, de szemléletes felirat segíti a látogatót, hogy minél világosabb fogalmat alkosson magának a szárnyasoltár eredeti helyéről.
A katalógusban a témát egy a kolostor és a templom alapítóira koncentráló történeti, genealógiai és heraldikai bevezető kezdi Radoslav Ragačtól. Ezt az épülettel kapcsolatos problémák követik, a vonatkozó fejezet Bibiana Pomfyová írása. Leszögezi, hogy az okolicsnói a legnagyobb gótikus templom egész Liptóban, és felhívja a figyelmet arra is, hogy milyen kevés háromhajós koldulórendi templom van az egész akkori Magyarországon. (Meglepő ez egy olyan faluban, amely még saját, ritkán lakott megyéjében sem számított a jelentékenyek közé.) A méreteken kívül különösen becsessé teszi az épületet - teszi hozzá - a belső tereket borító boltozatainak változatossága és eleganciája, a kivitelezés igényessége és az egyes hangsúlyos helyeken megjelenő címerek. Az templom mérete és kvalitása miatt régtől fogva ismételten felmerült, hogy királyi alapítás volt, és ennek a nézetnek a képviselői Mátyás és Beatrix címerének megjelenését is érveik közé sorolták. A szemben álló vélemény - ennek képviselöi főként szlovák kutatók - a helyi kezdeményezést hangsúlyozza, az alapítást és építést esetleg a szomszédságban lakó liptói nemesek érdemének tekinti. Ragač szerint a kezdeményező Okolicsnói Mihály volt 1476-ban, Mátyás királyt határozottan kizárja az építtetők közül. Úgy gondolja, hogy a királyi címerek is a feltételezhetően a még kiskorú Corvin János nevében tevékenykedett Kis Cecei Máté kívánságára kerültek a falakra, aki saját csekély jelentőségét akarta ezek révén emelni. (Cecei nemesi levele is látható volt a kiállításon, 23. kat. sz.) Pomfyová - Anton C. Glatz majd Jiři Fajt gondolatát tovább fejlesztve - azt fejtegeti, hogy az 1490-es évektől a finanszírozásban a Zápolyák játszottak döntő szerepet, talán megbízottjuk, az egy időben a szepesi várnagy és alispán szerepét is betöltő Szmrecsányi 


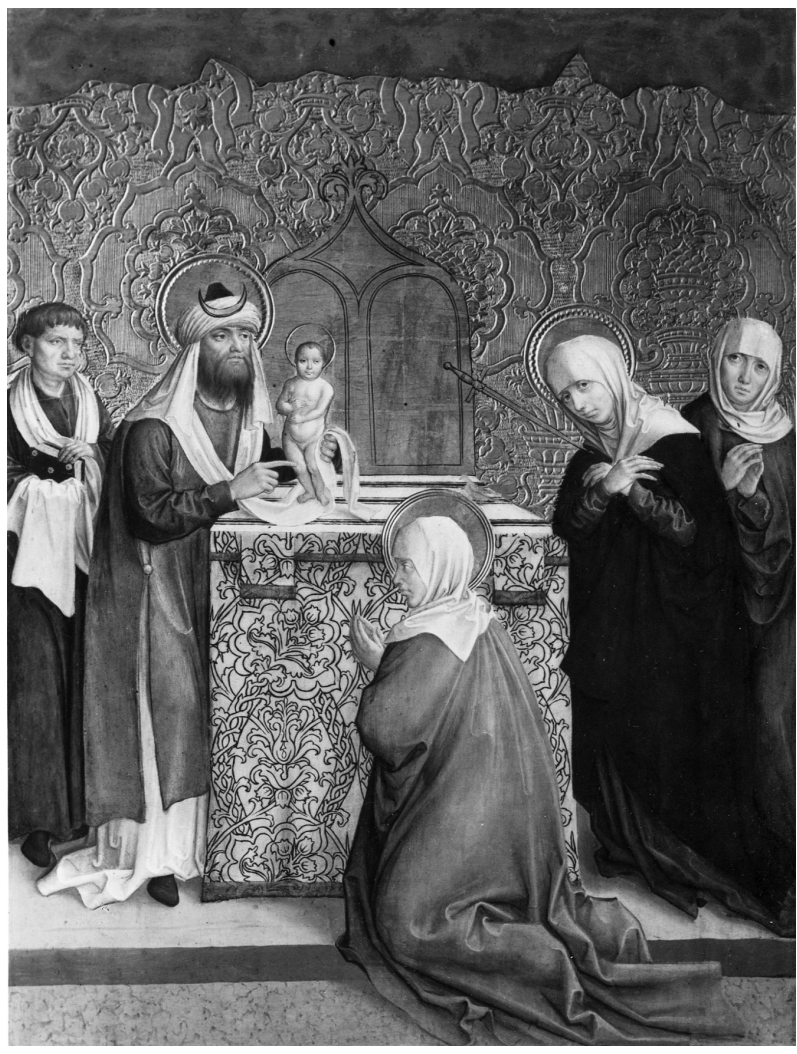

1. Bemutatás a templomban.

Az okolicsnói ferences templom föoltárának táblája, 1500-1510. Budapest, Szépmüvészeti Múzeum - Magyar Nemzeti Galéria

Kristóf közvetítésével. Fontos érve, hogy a nagyjából ugyanekkor emelt késmárki plébániatemplom és az okolicsnói között milyen sok apróbb megfelelés van, márpedig a késmárki a rajta elhelyezett címerek tanúsága szerint egyértelmüen az egyre nagyobb jelentőségre szert tevő Zápolya-család segítségével épült. Egy geometrikus jel, minden bizonnyal kőfaragójegyből kialakított mesterjegy előfordul mindkét helyen (bár Okolicsnón címerpajzsba foglalva, Késmárkon csak a déli kapubélletben, címerpajzs nélkül, és ez fontos különbség), tehát ugyanaz az építész tevékenykedhetett itt is, ott is.

A magyar kutatás, amelyet itt a Pomfyová írásában sürün idézett Papp Szilárd képvisel, változatlanul kitart a királyi alapítás 18. század óta elevenen élő gondolata mellett. Papp úgy véli, hogy az építkezés hazai viszonyokhoz képest igen nagy méretére és rendkívül igényes voltára való tekintettel egy ilyen templom emelése semmiképp sem lehetett egy (esetleg néhány) helybéli nemes család vállalkozása, itt már a korai fázistól kezdve csak a királyi kincstártól feltételezhető jelentős anyagi támogatásra volt szükség. Az épület sokkal nagyobb az akkori megyeszékhely, Liptószentmária megyei összefogásnak köszönhető templománál, tehát merőben valószínütlen, hogy csupán egy-két itteni birtokos ekkora épületet tudjon és akarjon emeltetni. Az obszerváns ferencesek támogatása egyébként Magyarország-szerte a Hunyadiakra jellemző. A templomban látható címerek között található a családja addigi jelentőségéhez képest hirtelen nagy jelentőségre emelkedett Kis Cecei Mátéé is, akinek címerét Papp ismerte fel az épülethez északról csatlakozó kápolna külsején és belsején. Az, hogy Kis Cecei, aki nem itteni birtokos, Liptóban Corvin János nevében tevékenykedik, királyi címert faragtasson, szintén erős érv a vállalkozás uralkodói volta mellett. Papp egyébként kételkedik a Zápolya-család részvételével kapcsolatban; kételyét erősíti, hogy bár ebben a templomban igazán sok címer látható, ám az övék sehol sem jelenik meg.

A kiállítás legfontosabb része természetesen a címszereplőnek, továbbá néhány, közvetlenül vele kapcsolatba hozható további alkotótársának munkásságát mutatja be. Az Okolicsnói Mester általános jellemzését, illetőleg a festményekről és a néhány kiállított szoborról szóló katalógustételek megírását a kurátor, Dušan Buran vállalta. Ô a bevezetőben leszögezte, hogy a vállalkozást nagyban megkönnyítette, szinte aktuálissá tette az a körülmény, hogy a kiállított táblák, sőt egész oltárok közül néhányat éppen az utóbbi időben restauráltak. (Egyes közvetlenül vagy közvetve idetartozó mü, például egy bártfai és egy kassai oltár, néhány faszobor ugyan hiányzott, ezeket azonban a katalógus szövege a többiekhez hasonló alapossággal tárgyalja.)

Az Okolicsnói Mester munkásságának összegyưjtését, az időrend és a sajátkezűség fokozatainak megállapítását már több szerző megkísérelte, a fentieken kívül feltétlenül említést érdemel Anton C. Glatz igen sok részletre kiterjedő, szinte teljes kutatástörténetet adó összeállítása. ${ }^{2}$ Mint a szükségnévvel jelölt mesterek munkásságánál általános szokás, a témához hozzászóló szakértők néha hozzátesznek, máskor elvesznek egy-két képet a lassan alakuló, formálódó œuvre-ből; az általános tendencia minden esetre az általa festett, vagy mühelye munkájának tekinthető képek számának lassú növekedése. Ezzel kapcsolatban egyetlen nevet hiányolok, Mojzer Miklósét. Ô volt az, aki felfedezte, hogy a ljubljanai Jézus rokonsága-kép idetartozik, a Szepességben készült - általánosságban egy lőcsei múvészre gondolt -, míg Emilijan Cevcnak egy kiállítási katalógusban tett megállapítása csak egy évvel később jelent meg, és már az Okolicsnói Mestert tekintette a kép alkotójának. ${ }^{3}$

Abban minden eddigi kutató egyet értett, hogy az Okolicsnói Mester tevékenysége a szepességi festészethez tartozik. Még a róla meglepően keveset, alig több mint egy oldalt író Radocsay is a 


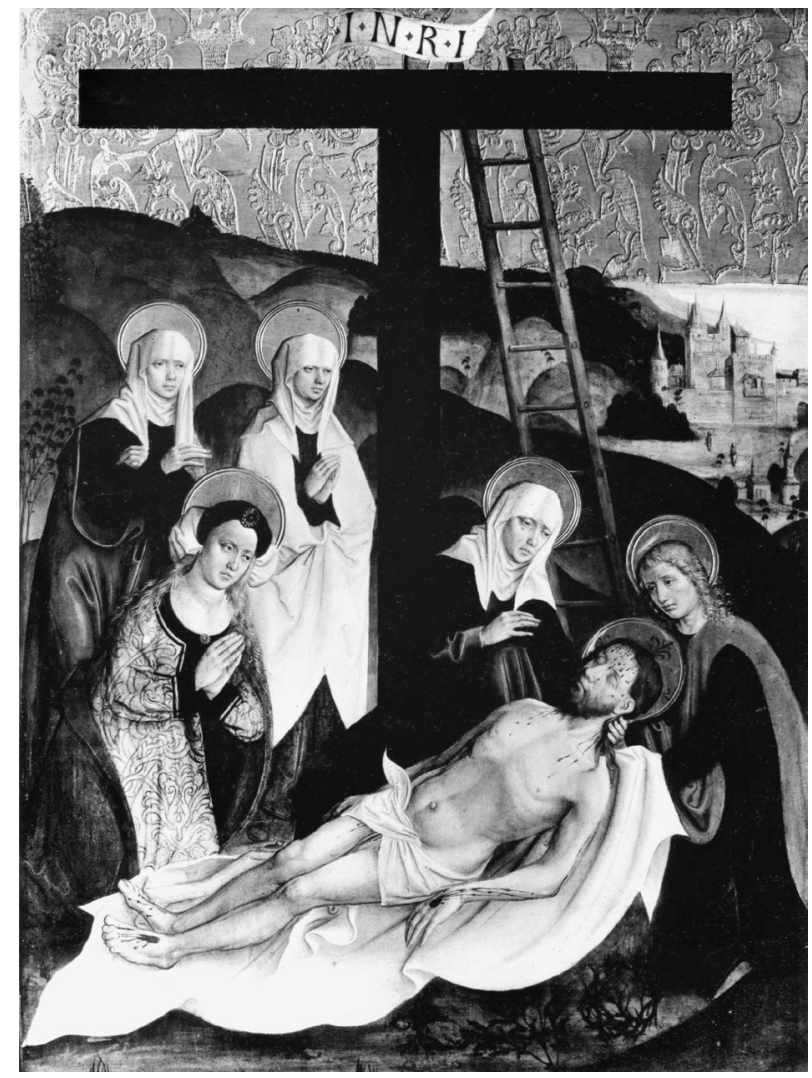

2. Krisztus siratása. Az okolicsnói ferences templom föoltárának táblája, 1500-1510. Budapest, Szépmüvészeti Múzeum - Magyar Nemzeti Galéria

szepeshelyi Mária koronázása-oltár hatását látta mûvészetén, pedig ô általában gondosan respektálta a nagyjából a megyehatárok által jelzett tájegységeket. ${ }^{4}$ Erich Wiese teljesen mellözte a mester személyét, túlságosan ragaszkodva ahhoz, hogy írása csak a Szepesség múvészetét dolgozza fel; az is igaz, hogy a szerzőtársával, Oskar Schürerrel együtt egy alapvetően topografikus könyvet író Wiesét nem nagyon kellett foglalkoztassa egy szomszéd megyére gyakorolt hatás lehetősége. Buran az eddigi kutatásnak megfelelően az állandóan emlegetett szepeshelyi oltár mühelyéből vezeti le az Okolicsnói Mester stílusát, feltételezve, hogy a festő maga is ott nyerte kiképzését.

A kurátor egyébként nem ért egyet azok törekvéseivel, akik a múveket meghatározott mesterekhez akarják kapcsolni, inkább úgy látja, hogy ezeket az 1500 körüli Szepességben a nagyobb volumenünek mondható munkákat egy - modern kifejezéssel élve - fővállalkozónak tekinthető festő készítette alkalmilag hozzá kapcsolódó társaival együtt, sőt egy-egy táblán is számolhatunk különböző kezek nyomaival. Még a szepeshelyi oltárok festői között a legnagyobb tekintélynek örvendő Mária koronázása oltárának Mestere mellett is ott dolgozhatott néhány mühelytárs vagy tanítvány, így az Okolicsnói Mester, a Hizsnyói és a Káposztafalvi Mester, talán még a Szent Antal oltárok Mestere és a szepesszombati Szent Anna-oltár festője is. (Az utóbbi feltételezés nem egészen meggyőző.) Az Okolicsnói Mestert inkább gyüjtőfogalomnak, nem annyira egy személynek, mint egy mühelynek, mégpedig nem is állandóan azonos tagokból álló mühelynek tekinti, ám nem hiszi, hogy az egyes festőket egyértelmüen el lehessen határolni.

Az Okolicsnói Mester legkorábbi munkájának a bártfai Mária és Erazmusz-oltárt tartja, és több munkatársát is felsorolja, aki feltételezése szerint itt együttmüködött vele. Az azonban aligha valószínü, hogy ezek között a nagyszalóki Szent Miklós-oltár festőjét is ott kellene találnunk; annak a mesterét az alakok plasztikusabb, húsosabb megfogalmazása, a szemek szinte mongolosan ferde metszése kizárja ebből az összefüggésből, és sokkal inkább a Szent Antal-oltárok Mesteréhez közelíti. Buran felveti annak a lehetőségét, hogy a tagadhatatlanul zsúfolt szekrényben jelenleg csak a 19. századi átalakításkor odakerült szobrok állnak (ha a gyanú jogos, eredetileg egy Mária halála dombormű lehetett a középen, minthogy mind a négy belső szárnykép közvetlenül erre vonatkozó jelenetet mutat), ám végülis valószínűbbnek tartja, hogy a figurák valóban odatartoznak.

A következő a mester első nagyszabású munkája, az okolicsnói oltár, de itt sem volt teljesen önálló; ezt az egész vármegyében vezető szerepet betöltő Pál mesterrel együttmüködve készítette. Az egyes képek brokátmustrájának vizsgálatából, amelyek hasonló formában a jeles szobrász más oltárain szintén megtalálhatók, a szerző arra következtet, hogy a munkálatok irányítója maga Lőcsei Pál volt, a középső részt egyébként is az ő szobrai töltötték ki. Ezt bizonyítja még, hogy az egyes gránátalmás, ananászos stb. minták rendre előfordulnak a vezető mester nevéhez köthető, vagy közvetlen közeléből származó, tehát az ő irányítása alatt tevékenykedő múhely oltárain. Az Okolicsnói Mester addigi munkáit vizsgálva feltételezi, hogy nem volt (még?) ilyen munkatársi köre. (A háttér brokátot imitáló mustráját készítő specialisták ugyanis a faszobrászok közül kerültek ki.)

Igaz ugyan, hogy Pál mester és mühelye a 16. század első évtizedében két, valóban nagy oltár (a lőcsei és a besztercebányai) felállításán dolgozott, de talán az általában 1510 előttre datált okolicsnói oltár mégis helyet kaphatott a feladatok között. Ezt erősítheti, hogy itt viszonylag kevés fafaragó munka volt. Buran ennek alátámasztására a dendrochronológiai vizsgálatokra is hivatkozik, egyébként hangsúlyozza, hogy Pál mester és mü- 


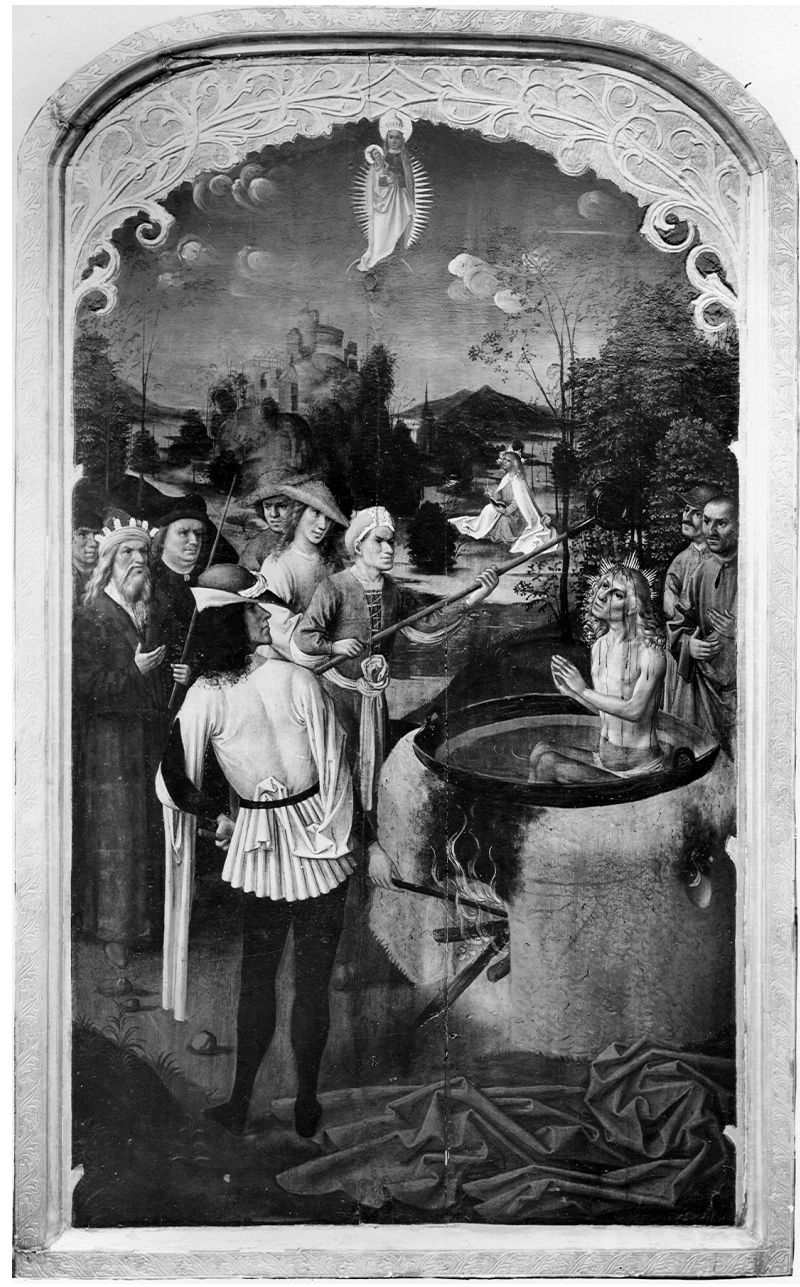

3. Szent János evangélista mártíromsága. Kétoldalán festett tábla a kassai Szent Erzsébet-templomból, 1510-1520. Kassa, Východoslovenské múzeum

helye képes volt egyszerre több párhuzamos munkát végezni. Egy probléma azonban így is marad: a két nem kevés munkát igénylő szmrecsányi oltáron 1510-es dátum olvasható. Így hát a művésznek is nevet adó alkotásnak, az okolicsnói oltárnak már ennél korábban el kellett készülnie, ám 1507-nél későbben, hiszen a Megostorozáson és a Tövissel koronázáson ekkorra datált Schäufelein-metszetek hatását látjuk; az persze megtörténhetett, hogy éppen ezeket festették utoljára, és az együttes többi táblája közül néhány addigra már többé-kevésbé készen volt. Minden esetre nagyon kellett igyekeznie, hogy rövid idő alatt is végezni tudjon, vagy pedig - amint a szerző sugallja - ugyancsak rá lehetett szorulva az általa irányított vagy egyszerüen vele együttműködni hajlandó festők munkaerejére.

Egyik-másik erőteljesen megfestett fej - főként férfifejek - láttán Burannak az a véleménye, hogy jó portréfestő lehetett, ez azonban nem bizonyítható. Egyébként nem is valószínü, hiszen ki festtetett vol- na vele portrét? Abban a korban a mi vidékünkön csak uralkodókról készültek képmások, erre egy szepességi polgár, akár egy kanonok, sőt a nagyhatalmú Zápolya-család esetében sem ismerünk példát. (Zápolya János ugyan ebben kivétel, de képmásai csak királlyá választása utáni évekből valók.) Még a több festményt megörzött területek, így Csehország vagy Lengyelország esetében is ugyanerre az eredményre jutunk. A férfifejek változatosak, általában markánsak, néha barnás árnyalatúak, a lágy, átszellemült női fejek, fehér fátylas női arcok ezzel szemben feltűnően hasonlítanak egymáshoz; ilyen különbségre Buran már a szepeshelyi Mária koronázása-oltáron felfigyel. Az arcoknak ez a szinte sztereotíp előadása a bártfai és a szmrecsányi oltárokon is látható, és bizonyosan előmozdította a munka gyorsítását. Erről a megoldásról az embernek egy két és fél évtizeddel ezelőtti stuttgarti kiállítás juthat az eszébe, ahol a katalógus szövege ismételten felhívta a figyelmet, hogy bizonyos megoldások feltünő hasonlósága egyértelműen a produkció gyorsítását, szinte tömegtermeléssé válását kellett szolgálja. ${ }^{6}$

A tájképi hátterek nagyon változatosak, számos esetben grafikai előképekre figyelhetünk fel, nem csak a lépten-nyomon emlegetett Schongauerre, Schäufeleinre vagy Meckenemre, de olyanokra is, amelyek általában nem tartoztak az 1500-es évek kelet-közép-európai festőinek érdeklődésébe (Világkrónika Hartman Schedeltől) - ezek egyenkénti előszámolása meghaladná a jelen ismertetés terjedelmét. Átvételei nyomán a festő ízlése konzervatívnak mondható, Dürer vagy Cranach nem szerepel a kiválasztott előképek között, pedig erre 1500 után a Szepességben már akadnak példák. Buran úgy véli, hogy bár a szepességi festészetből a 15 . század utolsó harmadáig teljesen hiányzik a táj, a századfordulóra Kis-Lengyelországgal együtt a tájfestészet legfontosabb kelet-közép-európai laboratóriumává vált. Az Okolicsnói Mesterhez kapcsolható munkákon nagyon változatos tájakat látunk a különböző múhelytársak stílusának megfelelően, magán a névadó oltáron néha ugyanazon a táblán. A Feltámadáson a kép bal szélén az orom és az alatta látható városrészlet szembetűnően modern a jobb félhez képest, ahol a barna szín különböző árnyalataival érzékeltetett sziklák a szepeshelyi főoltár külső tábláin látható, több évtizeddel korábbi megoldást ismétlik. (Ugyanazon a képen több kéz munkáját az is bizonyítja, hogy a Bemutatás a templomban táblán az alárajzoláson a később odafestendő szín neve vagy nevének kezdőbetüje oda van írva. Ez szintén a mühely racionális müködtetését mutatja.) Az erdők nagyon meggyőzően vannak ábrázolva, egyik-másik fánál az az érzésünk, hogy 
szinte botanikailag meghatározható. A belső terek a végletekig leegyszerúsítettek, a figurák térbeli elhelyezése nem mindig mondható tökéletesnek, az alakok néha szinte úsznak a levegőben, de Krisztus alakjának kiemelése mindig kellőképp sikerült.

Megrendelőjének személyét Buran nem tartja megállapíthatónak, nem csatlakozik azokhoz a mostanában ismételten felbukkanó nézetekhez, amelyek itt is a Zápolyák patrónusi szerepét látják. Végezetül említést érdemel, hogy kiemeli a szerzetesi templomhoz illő tartózkodó színhasználatot; a gazdag Kassa plébániatemplomában egészen mást fogunk látni; ott ",szinte hedonisztikus a színesség” - olvashatjuk szó szerint.

A két szmrecsányi oltáron látható címerrel kapcsolatban Buran feltételezi, hogy a megrendelö, az okolicsnói templom építésével kapcsolatban már emlegetett Szmrecsányi Kristóf (szepesi várnagy és alispán, utóbb szepeshelyi kanonok) lehetett az összekötő kapocs egy szepesi festő, az Okolicsnói Mester és egy liptói templom, az okolicsnói között. A szmrecsányi Szent Anna-oltár középképe, Anna hármas házassága - írja - bár bibliai alapot nélkülöző, tehát hevesen vitatott téma volt, de a kor szepesi művészetében feltűnően kedvelték. A figurák térbe helyezése itt sokkal jobban sikerült, mint Okolicsnón. Ez akkor is igaz, ha a külső táblákon látható Szent Erzsébet-jelenetek közül többön a figurák mögött egy kékes-szürke, minden térbeli vonatkozást kizáró hátteret látunk. Az infravörös vizsálat ugyanis megmutatta, hogy alattuk valódi terek vannak felvázolva, ám - idő hiányában? - ezek megfestése elmaradt. A Szent Márton és Miklós-oltár esetében a szerző joggal említi, hogy a horizont nem egybefüggő. Ismét láthatók a fentebb említett kis barna buckák, ismét müködhetett a rendkívül konzervatív iskolázottságú munkatárs. Habár nyilvánvalónak tartja, hogy ezeken egy időben több festő is dologozott, de a nemrégiben néha felmerülő kísérletekkel ellentétben mind a két oltárt magának a mesternek tulajdonítja, azaz nem érez kvalitás-különbséget közöttük. A markáns fejeknél itt is felveti, hogy egyik-másik rejtett portré lehet, de bizonyíthatatlannak tartja. Megjegyzi, hogy az egyik jellegzetesen „férfi-oltár”, csupa férfi szenttel, ellentétben a másikkal, amelyiken a Nagy Szent Család férfitagjaitól vagy az Erzsébet-legenda egyes mellékszereplőitől eltekintve csak nők láthatók.

A festő 1510 után eltünik, talán az abban az időszakban festett oltárai megsemmisültek, 1516-ban azonban ismét felbukkan egy ekkorra datált, Mária látogatásának szentelt kassai oltárnak köszönhetően. A szárnyak és a predella az Okolicsnói Mester legjobb színvonalát mutatják. Az arcok egyéniek, lágyan, tónusosan festettek (Buran ismét megem- líti, hogy a reneszánsz portrészerüség határán vagyunk), sokkal inkább, mint a mühely bármelyik eddigi munkáján. Még feltünőbb a tájképi hátterek megoldása: itt a szereplők, főként a külső táblákon egyértelműen nem a táj előtt, hanem benne állnak. Felveti az alighanem délnémet müvészek által továbbított németalföldi hatás lehetőségét, és talán ugyanabból az irányból jövő hatásnak tekinthető a légperspektíva alkalmazása. (Az eddigi szlovák irodalom inkább a sváb müvészetet, Zeitblomot és a hozzá hasonló zürichi vagy berni szekfüs mestereket, illetőleg az őrajtuk keresztül érkező olasz hatást emlegette.) Ezen az 1516-os munkáján nagyszerü koloristának látjuk a festőt, még az okolicsnói oltárhoz képest is.

Ezután következik a kassai dóm mindkét oldalán festett Szent János-táblája, kérdőjellel L. A. mesternek, a rozsnyói Mettercia festőjének tulajdonítva. Az Okolicsnói Mester kezétől származtatást vagy akár közvetlen közelébe helyezést - állapítja meg kizárja az ott megszokott lágyság, érzelmeség hiánya, itt a táj is jobban mélyül. A kettős Szent Jánostábla L. A. mester stílusához képest (akihez közel helyezi, de akitől Glatz-cal ellentétben nem származtatja ezeket) cselekményesebb, a táj ábrázolása kevésbé kulisszaszerü, a közeli és távoli figurák közötti feltűnően nagy lépték-különbség ez eddigiekhez viszonyítva szinte drámai. A felhőket feltünően hasonlónak látja a Szent Antal-oltárok Mesterénél láthatókhoz.

Bár ezzel véget ér a mesterhez és közvetlen mühelyéhez kapcsolandó képek sora, de joggal szerepel a kiállításon még két fontos kép, ezeket Buran a Káposztafalvi Mester ecsetétől valónak tartja. Az egyik a ljubljanai múzeumba került Nagy Szent Családkép, amit a szlovén kollegák által újra és újra megismételt attribúciójával ellentétben - Glatz-ot követve - nem a vezető mesternek, hanem egy vele azonos mühelyben tanult, de tőle független művésztől származtatja. (Glatz a három fő figurát egy jobb képességü festő munkájának látja, Buran ehhez nem csatlakozik.) Joggal veszi észre az aprólékosabb részletezésre, többek között a ruhák bőségesebb redőzésére való hajlandóságát, vagy azt, hogy a férfiarcokat milyen szívesen alakítja egymásról rendkívül különbözőre; ehhez még a színek, különösen a vörösök erőteljesebbé válását lehet hozzátenni. (A háttér szőlőmustrájának a jelentése azonban sokkal bővebb tartalmú, nem szorítkozik Krisztus vérére.) A másik egy talán Savnikról származó Krisztus az Olajfák hegyén, amelynél a Káposztafalvi Mester szerzősége melletti legfőbb érv a buja bokrok, erdők festése a Megváltó köré, és a Krisztus alak erőteljes, patetikus megfogalmazása, továbbá kolorizmusának „,szenvedélyes" volta; ez utóbbi talán kissé túlzás. A képnek 
hét másik, a Magyar Nemzeti Galériába került társával való kapcsolatát, a táblák eredeti elrendezését a katalógus szövegében egyedül említett Glatz előtt egyébként már Csánky Dénes megírta, a Káposztafalvi Mesterrel való összefüggést pedig Radocsay is tárgyalja corpusában.?

Ezután néhány szobor következik, ám ez egy festőnek szentelt kiállítás, itt a szobrokról kevés szó esik. (Az egykor az okolicsnói oltárhoz tartozó három szekrényfél-szobor, Pál mester munkái, előbbre kerültek, az oltár képeinek bemutatásához, 10 12. kat. sz. Részletesebb elemzést azonban ők sem kaptak.) A jelenleg az okolicsnói templomban, egy barokk oltáron álló Keresztrefeszített Krisztusban Buran az egykori diadalív figuráját látja, és az építkezéssel kapcsolatban a katalógus első fejezeiben szinte bizonyosságként kezelt Zápolya-megrendeléssel párhuzamosan késmárki párhuzamot említ: a hasonlóság valóban szembetűnő. Elfogadva Dobrosława Horzela véleményét, aki a késmárkit egy kis-lengyel műhely termékének találta, ${ }^{8}$ az okolicsnói diadalív-figurát is onnan eredezteti.

A kiállítást a kor réz- és fametszeteinek pazar válogatása zárta, nem kevesebb, mint 23 sokszorosított grafikai alkotás volt látható a 15 . század má- sodik feléből, E. S. mestertől, Schongauertől, Israhel van Meckenemtől, Wolgemuttól, de ismeretlen szerző munkája is van köztük. (Az ehhez tartozó szövegeknek Martin Čičo a szerzője, kétharmad részük esetében Burannal együtt.) A metszetek nagyrészt a kassai és a pozsonyi múzeumokból valók, de Brnóból, sőt Zürichből, a Technische Hochschule grafikai gyüjteményéből is kölcsönöztek. Az egyes tételeket kísérő szövegek elemzik az illető mester stílusát, de főként az Okolicsnói Mesterre és mukatársaira, esetleg már az őket szárnyra bocsájtó szepeshelyi mühelyre gyakorolt hatására mutatnak rá, az átvett részletek, motívumok eredeti összefüggését szemléletik; előfordul azonban olyan eset is (a 45. és 47. kat. sz.), ahol erről a hatásról szó sem esik.

Dušan Buran olyan kiállítást akart rendezni, amelyik - saját kifejezével élve - nem mondható „Blockbuster”-nek, de ennek a maga korában és vidékén igen jelentős mesternek alaposabb tanulmányozását teszi lehetővé. A kiállítás Liptó és Szepesség határain túlnyúló összefüggéseket is figyelembe vesz, és jól szolgálja a müvészi alkotás, a megrendelő és a közönség késő középkori kapcsolatának megértését. Az Okolicsnói Mesterről ezáltal megbízható monográfia született.

Végh János

\section{JEGYZETEK}

1 Vladimír Wagner: Príspevok k neskorogotickému maliarstvu severného Slovenska. In: Umenie dávne a nedávne (Vyber z diela Vladimíra Wagnera). Bratislava 1972, 59-89. Vele körülbelül egyidőben Csánky Dénes is felismerte a táblák öszetartozását, még szükségnévnek is ugyanazt alkalmazta, de publikációja valamivel később jelent meg. Csánky Dénes: Szepeshelyi táblaképfestészet a XV-XVI. században. Az Országos Magyar Szépművészeti Múzeum Évkönyvei VIII. 1935-1936, 68-84, 97.

2 Anton C. Glatz: Gotické umenie z košických zbierok. In: Gotické umenie z košických zbierok.Východoslovenské múzeum v Košicach, Slovenská národná galéria v Bratislave, Košice 1995, 62-70.

3 Mojzer Miklós: Lőcsei festő „Krisztus rokonsága” képe a ljubljanai Nemzeti Múzeumban. Művészettörténeti Értesítő XXXI. 1982, 226-227; Emilijan Cevc: Tuji slikarji od 14. do 20. stoletja. Ljubljana 1983, 50, 51, 53. kat. sz. Arra a kérdésre, hogyan kerülhetett egy késő középkori kép ilyen messzire, a Tátra aljáról a Muraközbe, jól megfelel egy táblaképnek a Szepességből a horvátországi Valpóba tervezett szállításáról szóló cikk ugyanabban a folyóiratszámban: Détshy Mihály: Adatok a lőcsei Bernát mester egy művéről 1519-ből. Művészettörténeti Értesítő XXXI. 1982,225

4 Radocsay Dénes: A középkori Magyarország táblaképei. Budapest 1955, 176-177.

5 Otto Schürer - Erich Wiese: Deutsche Kunst in der Zips. Brünn-Wien-Leipzig 1938.

6 Meisterwerke massenhaft. Die Bildhauerwerkstatt des Niklaus Weckmann und die Malerei in Ulm um 1500. Württenbergisches Landesmuseum, Stuttgart, Altes Schloß, 1993.

7 Csánky 1935-1936 i. m. (1. j.) 65; Radocsay 1955 i. m. (4. j.) 443-444, Glatz 1995 i. m. (2. j.) 71-72.

8 Dobrosława Horzela: Późnogotycka rzeźba drewniania w Małopolsce okolo 1440-1477. Kraków 2012, 55-77. 